\title{
Optimalisasi sistem pemberdayaan wakaf produktif sebagai alternatif sumber ekonomi umat
}

\author{
Muh. Shaleh Suratmin \\ Yayasan Wakaf Universitas Muslim Indonesia, Makassar
}

Wakaf is one of the main religious service which contains productive economic values but in reality the values haven't fully been implemented. The most important factor of this is the lack of socialization and the minimum role of the government (Badan Wakaf Indonesia). The enactment of the new wakaf bill (UU No. 41/2004) which followed by Peraturan Pemerintah Nomor 42 Tahun 2006 has not effective yet. How to maximize waqf advantages for society empowerment? This is the focus of study. The result of study shows that wakaf is very important to be the source of capital for empowering umat's economy. The way to understand (figh\}) wakaf must be reformulated. The maximization of productive wakaf needs proper public understanding and good management. That is why that the nadhir must fulfill moral, managerial, and entrepreneur qualifications. The writer conclude that only trough revitalizing the role of BWI and the public awareness, the new paradigm of waqf can be realized in Indonesia.

Keywords: Productive waqf; Empowerment; Economomic management; Welfare

\section{Pendahuluan}

Konsep Islam sebagai rahmatan li al-älamin senantiasa dipandang aktual oleh kalangan umat Islam. Salah satu argumen yang melegitimasinya, karena al-Qur'an secara tekstual telah merekomendasikan bahwa umat manusia sebagai satu keluarga, dan setiap manusia sama derajatnya dalam pandangan Allah swt. Untuk mewujudkan konteks kekeluargaan dan kebersamaan tersebut, mutlak harus dilandasi dengan prinsip dasar ta àwün, yakni bekerja sama dan tolong-menolong. 
Ijtihad, Jurnal Wacana Hukum Islam dan Kemanusiaan, Vol. 10, No. 2 Desember 2010: 215-236

Prinsip dasar tersebut antara lain dimaksudkan untuk meminimalisir jurang kesenjangan antara yang kaya dan yang miskin agar terpenuhinya hak dan kewajiban dalam kepemilikan harta benda. Mengacu pada konsep dasar tersebut maka kepemilikan harta benda berimplikasi hukum wajibnya membelanjakan harta itu sesuai dengan petunjuk al-Qur'an dan hadis, baik dalam konteks zakat, infaq dan wakaf.

Eksistensi wakaf perspektif ajaran Islam berada dalam ranah dimensi sosial, yaitu amaliyah dari seorang muslim yang menyerahkan harta bendanya untuk kepentingan ibadah yang bernuansa sosial. Orang yang menyerahkan hartanya untuk diwakafkan disebut wakif dan harta yang diwakafkan disebut mauqüf bib atau benda wakaf, penerima wakaf sesuai tujuan disebut Mauqūf 'alaih, sedangkan pengelola wakaf disebut nazir.

\section{Problematika sosial dan doktrin Islam}

Mencermati fenomena kehidupan bermasyarakat kontemporer dewasa ini, nampak adanya kecenderungan terjadinya polarisasi atau perbedaan yang semakin dahsyat, khususnya dalam status sosial ekonomi masyarakat, sehingga jurang pemisah antara orang kaya dengan orang miskin terlihat semakin jauh. Belum lagi perangai egois sebagian orang kaya yang justru cenderung semakin pelit untuk bersedekah membantu orang-orang yang miskin, bahkan berfoya-foya dengan hartanya untuk kepentingan subhat, memenuhi syahwat dunia guna meraih popularitas pribadi dengan menyuburkan gaya hidup snobisme.

Fenomena tersebut, tentu semakin mengusik rasa ketidakadilan ekonomi bagi masyarakat miskin pada umumnya. Sementara doktrin Islam menuntut adanya rasa keadilan dalam berbagai aspek, termasuk keadilan ekonomi atau kesejahteraan dalam masyarakat. Kendati konsep keadilan sosial ekonomi menurut Islam, tidak menuntut agar semua orang mesti menempati strata sosial ekonomi yang sama, namun naluri orisinalitas manusia cenderung berkeinginan untuk dapat hidup bermartabat dan terpandang dalam status sosial ekonomi. Akan tetapi kecenderungan itu, dapat disadari melalui komitmen dan doktrin Islam, bahwa perbedaan itu terjadi, antara lain karena fitrah dan potensi setiap orang juga berbeda.

Pada sisi lain dalam perbedaan status itu, ternyata ada hikmah dari ke-Mahakuasaan Allah yang justru merupakan akibat hukum dapat terwujudnya rasa kebahagiaan pada setiap individu manusia dalam kehidupan bermasyarakat dan bernegara, termasuk perbedaan strata 
dalam hal memperoleh rezki, seperti pada firman Allah: "Dan Allah melebihkan sebahagian kamu atas sebagian yang lain dalam hal rezki" (QS al-Nah] 16:71).

Ahmad M. Saefuddin (1987:48) mengelaborasi, babwa perbedaan dalam potensi kemampuan serta perbedasn dalam kesempatan dapat diduga sebagai sebab musabab dari perbedasn dalarn rezki yang mungkin ditecima oleh sescorang. Akibat lebih lanjut adalah lahirnya golongan kaya dan golongan miskin dalam masyarakat.

Penulis dapat toleransi terhadap pandangan tersebut, karena dalam kenyataannya doktrin Islam sebagaimana makna surah al- $\mathrm{Nahl}$ ayat 71 secara utuh. Dari ayat tersebut dipahami konteksnya, bahwa sekalipun rezki manusia tidak sama, namun sekifanya otang-orang kaya bersifat amanah mengcluackan scbagian hartanya untuk hak-hak orang rniskin, maka niscaya onang yang miskinpun dapat merasakan kebahagiaan dari akibat hukum bantuan harta orang-orang kaya itu. Bagaimana optimalisasi pemberdayasn wakaf produktif sebagai altematif sumber ekonomi umat di Indonesia yang memiliki tanah wakaf seluas 5 kali Negana Singapura? Polkok permasalahan tersebut dapat dielabocasi melalui penelusuran dan identifikasi sumber-sumber hukum Islam perspektif al-Qur'an dan hadis, pandangan para ularna dan Undang-Undang Perwakafan dengan pendekatan tcologis normatif, yunidis, historis dan sceiologis.

\section{Wakaf perspektif al-Qur'an}

Dalam al-Qur'an terdapat beberapa petunjuk atau pedoman bagi sesecrang untuk membelanjakan hartanya, baik untuk kepentingan dirinya, maupun untuk kemaslahatan orang lain, seperti dalam firman Allah;

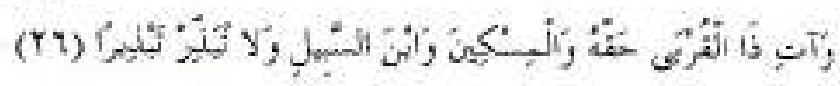

"Dan berikanlah haknya kepada kerabat dekat, juga kepada okang miskin dan orang yang dalam perialanan; dan janganlah kamu menghambur-hamburkan hartamu secara boros" (QS, al-Ista' 17:26)

Di samping itu, dalam ajaran Islam ada beberapa lembaga yang dapar dipergunakan untuk tnendistribusikan sebagian harta seseorang untuk kepentingan sosial atau kemaslahatan umat. Salah satu lembaga yang sangat potensial adalah "usikat". 
Jjtihad, Jurnal Wacana Hukum Isłam dan Kemanusiaan, Vol. 10, NNo. 2 Desember 2010:215-236

Wakaf adalah salah satu lembaga jang sangat dianjurkan oleh ajaran fslam untuk dipergunakan oleh seseorang sebagai sarana penyaluran rezki yang dikarunjakan Allah kepadanya. Meskipun wakaf tidak secara tekstual disebutkan dalam al-Qur'an, namun sejumlah ayat yang memerintahkan manusia untuk berbuat baik khususnya dalam membelanjakan harta untuk kemaslahatan umat, oleh para ahli memandangnya sebagai dasar hukum perwakafan. Seperti dalam firman Allah: "Kamu tidak akan memperoleh kebajikan, sebelum kamu menginfakkan sebagian harta yang kamu cintai” (QS. Ali 'Imrān 3:92).

Wakaf adalah salah satu lembaga Islam yang mendapat pengaturan secara khusus dalam peraturan perundang-undangan yang berlaku di beberapa negara Islam, termasuk di Indonesia. Dengan demikian wakaf merupakan salah satu pranata hukum Islam yang diatur secara konkrit dengan peraturan perundang-undangan yang berlaku di Indonesia. Wakaf adalah salah satu lembaga Islam yang bersifat sosial kemasyarakatan, bernilai ibadah dan sebagai pengabdian yang tulus kepada Allah swt.

Dilihat dari segi bentuknya, wakaf kontemporer dapat dipahami dalam dua kategori, yaitu wakaf benda tidak bergerak, dan wakaf benda bergerak (Hasanah, 2004: 123). Perkataan waqf, atau wakaf dalam bahasa Indonesia, berasal dari kata kerja bahasa Arab "Waqafa, Yagifu, Waqfan" yang berarti tagu-ragu, berhenti, memberhentikan, memahami, mencegah, menahan, mengaitkan, memper-lihatkan, meletakkan, memperhatikan, mengabdi dan tetap berdiri (al-Munawir, 1984:1683). Term wakaf menurut 'Abd al-Wahhab Khallaf, wakaf berarti menahan sesuatu baik ḥissi (wujud) maupun maknawi. Kemudian kata wakaf tersebut juga digunakan untuk obyeknya yakni dalam arti sesuatu yang ditahan (Khallaf, 1951:14).

Menurut Muhammad ibn Isma il al-Shan'any, wakaf adalah menahan harta yang mungkin diambil manfaatnya tanpa menghabiskan atau merusak bendanya dan digunakan untuk kebaikan (al-Shan'any, t.t. Juz III: 114).

Sedangkan menurut Abu Hanifah, wakaf adalah penghentian benda tidak bergerak dari pemilikan wakif secara hukum dan penyedekahan manfaatnya untuk kemaslahatan umum. Oleh karena itu barang yang diwakafkan tidak harus lepas dari pemilikan wakif dan sah bagi wakif menariknya kembali serta boleh menjualnya.

Menurut Abu Hanifah, wakaf dapat ditarik kembali oleh wakifnya, kecuali jika terdapat. alasan sebagai berikut: Pertama, hakim memutuskan bahwa wakaf tetap. Hal ini terjadj jika 
ada per-sengketaan antara wakif dan wazi. Kedua, Hakim menggantungkan berblanya wak af pada kematian wakif. Misalnya wakif berijab, "A pabila saya wafat, maka saya wakatkan rumahku", maka waksf itu harus dilaksanakan sebagzimana diwasiatkat, yakni secelah wakif wafat. Ketiga, Apabila sesconang menjadikan wakafnya itu sebagai masjid, dan wakif itu mengizinkan di dalam wakaf tersebut untuk shalat. Apabila sudah ada sescorang salat da mesjid tersebut, menurut Abu Hanifah, gugurlah wakaf tersebut dari pemilikan wakif. Penetapan ketentuan tersebut tidak bertentangan dengan ketentuan Allah (al-Zuhayli, t.t; 153; al-Kubaisy, 1977: 66-67).

Meskipun Abu Hanifah berpendapat bahwa harta yang diwakafkan dapat ditarik kembali oleh wakif, namun di sisi lain Abu Hanifah juge berpendapat bahwa jika terjadi perselisihan ancara wakif dengan naz̧ir, maka hakim mempunyai otoritas untuk memutuskan wakaf tersebut harus bersifat abadi dan tidak boleh citarik lagi oleh wakif.

Adapun menurut Jumhur lyang termasuk di dalamnya adalah kedua sahabat Abu Hanifah, yakni Abu Yusuf dan Muhammad bin al-Hasan, golongan Syafitiyah dan golongan Hanabilah), wakaf adalah menahan harta yang memungkinkan diambil manfaatnya, tetap "ainnya (benda yang diwakafkan), dibelanjakan oleh wakif untuk mendekatkan dis kepada Allah. Harta wakaf atau basilnya dibelanjakan untuk mendekatkan diri kepada Allah. Dengan diwakafkannya itu, harta keluar dari pemilikan wakif, dan secars hukum harta wakaf tersebut milik Allah. Bagi wakif terhalang untuk memanfatkan dan wajib mendermakan hasilnya sesuai tujuan (mangif ialog) (Zahrah, 1971:41). Dalam konteks ini jumhur ulama menggumakan dalil, dengan hadis Ibnu 'Umat yang menyedickahkan sebidang tanahryya di Khaibat.

Al-Zuhayli berpendapat bahwa hadis tersebut menunjukkan adanya latangan membelanjakan harta yang diwaksfkan, karena sesungguhnya al-habs artinya menghalang yakni mengbalangi 'wo untuk dimiliki atau dibelanjakan sebagaimana harta pemilikan. Akan tetapi hacis tersebut tidak menunjukkan bahwa harta yang diwakafkan tersebut keluar dan pemilikan wakif.

Di samping itu jumhur ulama juga member alasan bahwa umat Islam sejak darangnya Islam sampai dengan sekatang terus-menerus mengamalkan wakaf untuk kebaikan dan menghalangi wakif untul membelanjaksn harta wakaf tersebut. Adapun menurut golongan Malikiyah wakaf berarti pemilik harta memberikan manfast harta yang dimiliki bag para 
mustahik. Harta tersebut dapat berupa benda yang dsewa kemudian hasilnya diwakafkan. Hasil harta yang diwakafkan itu capat berupa benda-benda tertentu. Bahkan golongan Malikiyah berpendapat bahwa hasil barta wakaf yang berupa uangpun dapat diwakatkan asal dimanfaatkan untuk kebaikan. Oleh karena itu golongan Malikiyah tidak mensyaratkan benda yang diwakafkan bersifat kekal. Misalnya pemilikan melalui sewa, yakni seseocang menyewa rumah atau tanah untuk dimiliki dalam wakm tertentu, kemudian ia mewakafkan hassl atau manfaat benda yang đwakafkan itu kepada para mustabik selama masa itu juga Adapon yang dimaksud dengan pernilikan menurut golongan Malikiyah ini bisa pemilikan zat barang tersebut dan bisa juga pernilikan manfaat

Menumi golongan Malikiyah, wakaf tidak menyebabkan putusnya hak pemilikan terhadap 'ain, yang terputus hanya hak membelanjakannya. Mereka memberikan dasar hukum mengenai tetapnya pemilikan pada barsng yang diwakatkan dengan hadis "Umar yang marannya meayebutkan: "Jika engkau mau, tahanlah astinya dan sedekahkan manfaamya".

$\mathrm{Hal}$ ini menunjukkan bahwa yang disedekahkan itu hanya basilnya, dengan demikian harta yang diwakafkan tetap menjadi milik wakif. Hanya saja wakif dilarang untuk mentasarufkan dalam benouk usaha pemilikan pada pihak lain. Pernahaman ini betsumber dari dalil 'Umat juga (al-Zuhayli, t,th. 156; Zahrah, 1971: 43). ("Ágar tidak dijual, tidak dihibahkan dan tidak diwariskan"y

Hal ini berarti bahwa menurut golongan Malikiyah meskipun status harta yang diwaksflkan tetap menjadi milik wakif, namun wakaf harus dibelanjakan sesuai dengan tujuan wakif. Is tidak berhak menjual menghibahkan atau mewariskan kepada pihak lain. Sementara golongan Hanafiyah berpendapat bahwa wakif boleh menarik harta yang diwakafkan dan boleh menjualnya kecuali hakim menetapkan wakaf in tidak boleh ditarik kembali. Meskipun demikian, para ularna sepakat bahwa wakaf masjid termasuk dalam bab pembebasan dan pelepasan, tidak ada pemilikan bagi sescorangpun di dalamnya, karena masjid adalah milik Allah swt.(al-Zuhayli, t.th: 153).

Dari beberapa rumusan yang telah dikemukakan mendeskripsikan, umumnya para ulama berpendapat bahwa harta benda yang telah diwakatkan oleb wakifnya, maka akibat hukumnya hatta wakaf tersebut menjadi milik Allah swt. Sementara sebagian golongan Hanafiyah dan golongan Malikiyah berpendapat bahwa pemilikan harta yang diwakafkan itu tidak harus 
lepas dari wakif, yang diwakafkan itu adalah manfaatnya, sedangkan pemilikan tetap ada pada wakif, karena yang terputus bagi wakif hanyalah hak-hak untuk membelanjakan. Hanya saja wakif tidak bebas memanfaatkan harta yang diwakafkan.

Menurut golongan ini jika seseorang telah mewakafkan hartanya, pemilikan atas harta tersebut tidak terputus, akan tetapi dia tidak boleh menjual, menghibahkan dan mewariskan harta yang sudah diwakafkan itu. Hanya saja karena benda yang diwakafkan tidak disyaratkan lepas dari pemilikan wakif, maka golongan Malikiyah memperbolehkan manfaat wakaf dari sesuatu yang disewa, dan karenanya mereka berpendapat bahwa syarat wakaf tidak harus ta'bid (abadi).

Sisi kebaikan pendapat golongan Malikiyah ini, karena orang yang ingin berwakaf tidak harus dengan harta benda hak milik, akan tetapi cukup dengan menyewa harta benda yang dapat diwakafkan hasilnya. Akan tetapi di sisi lain pendapat ini akan berimplikasi lemahnya lembaga wakaf dan tidak sesuai dengan pendapat Jumhur ulama yang mensyaratkan, bahwa harta yang diwakafkan harus tetap zatnya dan dapat dimanfaatkan secara terus-menerus.

Elaborasi terhadap uraian yang telah dikemukakan mendeskripsikan adanya perbedaan pendapat dikalangan 'ulama mengenai status dan kriteria harta benda wakaf. Oleh karena itu tidaklah mengherankan apabila penentuan sah tidaknya wakaf juga terdapat perbedaan. Tetapi letak perbedaannya bukan dalam hal yang prinsip. Pada konteks hal-hal yang pokok tetap ada ukuran-ukuran yang disepakati oleh jumhur ulama. Sah atau tidaknya wakaf tersebut, jelas erat kaitannya dengan syarat dan rukun-rukun wakaf.

Di beberapa negara khususnya di Timur Tengah, wakaf telah berkontribusi sangat signifikan, bukan hanya untuk pengembangan dimensi ibadah dan pendidikan, tetapi juga dapat memacu mercusuar kemaslahatan umum seperti lahan pertanian, perkebunan, uang, saham, real estate dan sebagainya, yang semuanya telah dikembangkan secara produktif (Zahrah, 1971: 13).

\section{Sistem pemberdayaan wakaf produktif di Timur Tengah}

Bertolak dari uraian terdahulu dan fokus kajian tentang optimalisasi sistem pemberdayaan wakaf produktif sebagai sumber umat, adalah sesuatu yang logis apabila ditelusuri dari berbagai pendekatan. Walaupun wakaf merupakan lembaga Islam yang hukumnya sunah, 
ljtihad, Jurnal Wacana Hukum Islam dan Kemanusiaar, Vol. 10, No. 2 Desembcr 2010: 215-236

camun lembaga ini dapat berkembang sangat baik di beberapa negara sepcrti Mesir, Saudi Arabia, dan Yorcania. Hal ini dapat diduga kuat karena lenbaga wakaf tclah dikelola dengan manajemen yang baik sehingga manfaatnya sangat dirasakan oleh mus.tahiq (Suratmin, Disertasi 2009: 12).

Dengan mencermati beberapa hasil studi perwakafan menunjukkan, hahwa salah satu faktor yang mendasari lembaga wakaf dapat tumbuh pesat di belerapa negara khususnya di Mesir, Saudi Arabia, dan Yordania, hal itu disebabkan karena lembaga wakaf dapat berkontribusi secara signifikan dan sangat dirasakan manfaatnya untuk kesejahteraan umat. Di samping itu, faktor kebajikan manajemen pengelolaan dan landasan hukum yang valid, akan sangat berpengaruh signifikan terhadap pengembangan wakaf secara produktif. Kevalidan pengelolaan wakaf secara produktif di beberapa negara di Timur 'l'engah, juga merupakan implikasi adanya struktur lembaga Departemen dan Kementrian Perwakafan. Kedahsyatan ekonomi perwakafan produktif baik di Mesir maupun di Saudi Arabia, karena dana wakaf sewaktu-waktu dapat menjadi dana talangan untuk keuzngan negara (Mannan, 2001: 51).

Dalam lintas sejarah yang panjang menunjukkan, bahwa kuntribusi wakaf khususnya terhadap operasional pendidikan di Universitas Al-Azhar di Kairo Mesir telah herusia lebih dari 1.000 tahun. Sejak didirikan hingga kini, Al-Azhar merekrut mahasiswa dari 98 negara di dunia dengan jumlah mahasiswa sekitar 450 ribu orang ditopang oleh pendanaan dari perputaran aset wakaf yang dimiliki. Bukan hanya wakaf tanah, gedung dan lahran pertanian, tetapi juga wakaf tunai (Djunaidi, 2005).

Dengan dana wakaf yang super besar, Al-Azhar mampu membiayai operasional pendidikan selama bcrabad-abad. Untuk bidang ilmu-ilmu agama Al-Azhar tidak memungut biaya studi, bahkan di bidang ilmu umum seperti Kedokteran, Farmasi, Perdagangan dan sebagainya juga mondapat subsidi dari dana wakaf yang relatif besar. Di samping itu AlAzhar juga mengelola ratusan sekolah dan perguruan tinggi yang menyebar di wilayah Mesir, dan bebcrapa cabang di luar ncgeri berupa puluhan rumah sakit, panti sosial, dan penyevaan lahan bisniș (Departemen Agama RI 2004: 18).

Pengkajian lembaga wakaf yang ada di Mesir sebagaimana telah diuraikan, memberi deskripsi yang jelas bahwa wakaf di Mesir dikelola secara produktif dan telah memberikan 
Optimalisas sistem pemberdayaar wakel froduktif ...(Muh Shaleh Suratmin!

kontribusi yang besar terhadap kemeslahetan umat ci bidarg sosial, agema, pendid kan dan keluudayaan serta ekonomi. Pcmanfaatan wakaf di Mesir telah mendiskripsikan, bahwa wakaf telah berkontribusi secara dalısyat, terutzma kontribusinya di bidang perdidikan, pertanian dan kesehatar.

\section{Paradigma wakaf di Indoncsia}

Di Indonesia, wakaf telah dikenal dan dilaksanakan oleh umat Islam scjak agama Islam masuk di Indonesia. Sebagai suatu lembaga Islam, wakaf telah menjadi salal: satu penunjang perkembargan masyarakat Islam. Sebagian besar rumah ibadah, perguruan Islam dan lembaga-lcmbaga kcagamaan Islam lainnya dibangun di atas tanah wakaf.

Menurut pengamatan dan telaah penulis, Undang-Undang Perwakafar di Indeonesia telah diberiakukan selama kurun waktu 5 tahun terakh ir, tetapi keryataannya bclum cfcktif secara signifikan untuk melakukan berbagai perubahan ke arah wakaf produktif, hal iıu ada beberapa alasan yang mendasar. Selain kurangnya sosialsasi mengenai Peruncang-undangan Wakaf kcpada masyarakat, juga karcna kurangnya perhatian pemerintah untuk lebih metekomerdasikan bahwa wakaf sebagai salah satu alternatif sumber ckonomi umat yang sangat pozensial.

Di samping itu, karena umumnya nazir kurang profesional, sehingga pengelolaan wakaf cenderung konvensional. Juga dimungkinkan kurangnya sentuhan dakwah Islam yang dapat mcrangsang masyarakat untuk berwakaf, sementara pemahaman perwakafan yang melekat pada masyatakat Indonesia cenderung dipengaruhi oleh mazhab Syafic, bahwa harta yang bisa diwakafzan adalah rarta xenda tidak hergerak seperti anah can bangunan. Oleh karcna itu wakaf benda bergerak dan wakaf tunai memerlukan strategi sosialisasi yang (optinal kepaca masyarakat.

Pcnulis berpandangan bahwa nazirmerupakan "sakaguru" keberhasilan dalam pengelolaan perwakafan, dan oleh karena jtu, syarat naziir antara lain harus protesional dan amanah. Apabila para nazir tidak memiliki persyaratan tersebut, maka dampaknya sangat besar terbadap lunturnya kepercayaan masyarakat untuk berwakaf.

Wakaf merupakan ajaran agama Islam yang berhubungan dengan penyerahan dan pengelolaan harta benda untuk kemaslahatan umat dan kesejahteraan sosial pada umumnya. 
Ijtihad. Jurnal Wacara Hukum Islam dan Kemanusiaan Vol. 10, No. 2 Desember 2010: 215-236

Menurut Didin Hatidhuddin, hikmah dan manfaat wakaf dapat dirumuskan sebagai berikut: Periama, menunjukkan kepeculian dan tanggung jawab terhadap kebutuhan masyarakat. Kidwa, keuntungan moril bagi wakif dengan mendapatkan pahala kcbajikan yang mengair terus, walaupun wakif sudah meninggal dunia. Ketiga, memperbanyak aset yang dapat digunakan untuk kepentingan umum yang sesuai dengan ajaran Islam. Keempat, merupakan sumber data potensial bagi kepentingan peningkatan kualitas umat, seperti pendidikan, kesehatan, kesejahteraan dan sebagainya (Hafidhuddin, 2004:197).

Ajaran ini sudah dipraktikan sejak zaman Nabi Muhammad saw dan berlangsung terus hingga pada waktu sekarang. Ajaran ini telah dikenal dan dipraktikan di Indonesia untuk waktu yang lama. Sejumlah sarana keagamaan dan sosial di tanah air dibangun dengan dana yang bersumber dari wakaf umat Islam. Sarana tersebut dapat disaksikan di kawasan perkotaan dan pedesaan. Walaupun demikian, penerapan ajaran wakaf di Indonesia sccara umum belum juga optimal.

Gambaran seperti dikemukakan di atas akan terasa bila pengelolaan wakaf di Indonesia diamati dcngan cermat. Orientasi penyaluran wakaf masih sangat terbatas, terurama untuk keperluan sarana ibadah dan pendidikan agama. Jumlah usaha sosial lainnya milik umat Islam masih sedikit dibandingkan dengan potensi umat yarg sedemikian besar. Scbagian dari usaha itu berkembang dengan baik, namun ada juga di antaranya yang beraca dalam kondisi vailit, gersang dan sangat memprihatinkan. Bahkan ada di antara wakaf tersebut yang berpindah tangan. Dengan demikian, perkembangan wakaf masih kurang, baik dari segi kualitas maupun kuantitasnya.

Kajian tentang wakaf di kalangan umat masih perlu dikembangkan dari aspek permahaman dan penghayatan, serta aspek pengelolaannya. Koncisi wakaf dan pengelolaannya tcrkait dengan pandangan masyarakat tentang hal tersebut di samping pengalaman mereka yang masih terbatas. Sudah sewajarnya jika kondisi itu diupayakan penanggulangannya secara bcrsama-sama oleh para ulama, intelektual, pejabat pemerintah, dan pemuka masyarakat. Perlu berbagi pengalaman untuk mengatasi kelemahan dan kendala yang melilit umat dalam hal penerapan ajaran agama ini, sehingga bisa lebih berdaya guna untuk kesejahteraan umat atau masyarakat. 
Optimalisasi sistern permberdayaan wakaf prod..ktif ...(Muh. Shalch Suratrin)

Di Indoncsia sedikit seliali tanah wakaf yang dikeloa secara produktif dalam bentuk usaha yang hasilnya dapat dirnanfaatkan bagi phak-pihak yang momerlukan termasuk fakir miskin. Pemanfaatar. tersebut dilihat dari segi sosial khususnya untuk kepentingar keaganidan memang eiektif, tetapi dampaknya kurang berpengaruh positif dalam kehidupan sosial ekonomi masyarakat. Apabila pcruntukan walkaf hanya terbatas pada hal-hal di aras, tanpa diimbangi dengan wakaf yang dapat dikelola secara produkif, maka wakaf sebagai salah satu sarana untuk mewu udkan kesejahteraan umat, tidak akan dapat terealisasi secara optimal. Padahal wakaf dalam hubungannya dengan pembangurran sangat jelas, karena yang melaksanakan pembangunlar. nasional ini adalab. masyarakat dan pemerintah. Masyarakar acalah pclaku utama pembangunan dan pemerintah berkewajiban untuk mengarahkan, membimbing, serta menciptakan sưasana yang menunjang dan konstruktif. Uintuk itu kegiatan masyarakat dan kegiatan pemerintah harus saling mendukung, saling mengisi, dan saling melengkapi dalam satu kesatuan langkah menuja tercapainya tujuan pembangunan nasional tersebut.

Wakaf dalam furgsinya sebagai ibadah, diharaukan menjadi bckal kehidupan wakif di hari Aklirat. Wákaf adalah suatu benzuk amal yang pahalanya akan terus menerus mengalir selama harta wakaf :tu dimanfaatkan untuk kemaslahatan umat. Sedangkan dalam fungsi sosialnya wakaf mcrupakan aset yang sangat bernilai dalam pemhangunan. Wakaf selain sebagai usaha pembentukan watak dan kepribadian seorang muslim untuk melepas sebagian harlanya untuk kepentingan orang lain, juga merupakan investasi pembangunan yang bernilai tinggi tanpa memperhitungkan langka waktu dan keuntungan materi bagi orang yang mewakafkaz. Peranannya dalam pemerataan kesejahteraan di kalangan umat dan penanggulangan kemiskinan termasuk di antara sekian sasaran wakaf dalam ajaran Islam (Zein, 1991: 38).

Dengan demikian jika wakaf dikelola dengat: baik tentu sangat menunjang pembangunan, baik di bidang ekonomi, agama, sosial budaya, politik, maupun pertahanan dan kearrıanan. Menurut Rachmat Djarnika, dalam bidang ekonomi, wakaf memegang peranan semacam pershock-breaker dalam keseimbangan kehidupan masyarakat karera dapat menutupi kebutuhan masyarakat yang vital (Djatnika, t.t.: 78). 
Ifthad, Jurnal Wacana Hikum Islam dan Kemanusiaen, Vo. 10, No. 2Desember 2010: 215-236

Pendapat di atas dapat ditcrima harena tanah wakaf yang ada dapat dipergunakan unnk mendirikan tempat-tempat ibadah scperti, masjid, langgar dan musballa, untuk pemenuhan samana keschatan seperti poliklinik, puskesmas, atau tumah sakit, untuk tomah yatim piatu, madrasah, sekolahan atau pesantren, pasat, pertanian, jalan, pembangunan kantor dan sebagainya. Unruk pemeliharaannya dapat diambilkan sebagian tanah wakaf yong mungkin dikelols secara produktif, baik unwk tanah pettanizan maupun untuk mendirikan bangunanbanguman yang kemudian disewakan sehingga menghasilkan dana yang diperlakan untuk pemeliharaan barta wakaf pang lain. Dengan demikian wakaf tidak hanya mempunyai peranan dan fungsi keagamaan, terapi juga mempunyai fungsi senttal scbagai suatu potenai yang dapat menghasilkan, dan sebagai instrumen untuk keseimbangan sosial ckonomi.

Dengan mencermati beberapa hasil studi perwakafan menunjukkan, bahwa pengelolasn wakaf produktif di Indonesia belum signifikan, bahkan secara empins tanah wakaf Indonesia sebagian besar masih memprihatinkan. Namun demikian schuma 5 tahun terakhir embrio wakaf produktif di Indonesia yang berskaha internasinal relah dapat disodentifikasi, antara lain Yayasan Wakaf Universitas Muslim Indonesia (UM) Makassar dan Yayasan Wakaf Universitas Islam Indonesia (UII) Yogyakarta. Pemilihan sampel kedua yayasan tersebut sangat beralasan apabila menggunakan parameter sistem manajemen Otonomi Berkehormatan dan Berkebaipkan dalam pergelolaan pendidikan dan nilai-nilai kemaslahatan umat yang sudah dicapai.

\section{Yayasan wakaf universitas muslim Indonesia (UMI) Makassar}

Yayasan Wakaf UMI telah mewujuckan sehahagian dari apa yang tclah dicia-citakan, dengan berdininya tiga pilar utama Yayasan Wakaf UM1 yaitu: Kontribusi Tethadap Pendidikan dan Dakwah dengan Lembaga Pendidikan yang dibina Yayasan Wakaf UMI sejak 1954: terdiri dari 1) Lembaga Pendidikan Persiapan UMI (LPP-UMD):Sekolah Mengengah Pertama (SMP), Sekolah Menengah Atas (SMA), Sekolah Menengah Kejuruan (STM dan SMEA); 2) Lembaga Pendidilan Tinggi:Universitas Muslim Indonesia, dengan 12 fakultas; Program Pascasarjana, dengan 4 Progtam Studi Magister (\$-Z) dan 2 Program Studi Doktor (\$-3); Akademi Bahast Asing (ABA) Jurusan Bahasa Inggris. 3) Lerrbaga Pendidikan Pesantren:

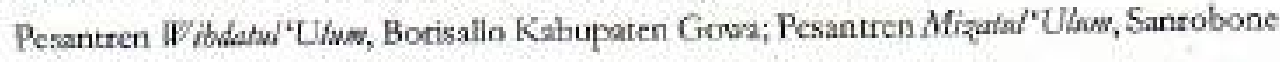
Kabupaten Takalar; Pesantren Mahasiswa Dar af-Makhutsim Pudanglampe Kabupaten Pangkep 
Optirnalisasi sistem pemberdayaan wakaf produktif ...(Muh. Shaleh Suratmin)

Dattar nama-nama yang tencrima amanalı sebagaj Rektor UMI (Buku panduan IJMI Makassar tahun 2008/2009: 17) sejak berdirinya sampai sckarang adalah: Prof. Mukhtar Lintang (Presidiunn) (1954-1958), Prof. Abd. Rahman Syihab(1959 - 1965), Latunrung (19651967), Ahmad Dara Syahruddin (1967-1970), H. Ridwan Saleh Mattayang, SH (1971 1976), H. M. Hijaz Yunus, SH (1976 1984), Prot. Dr. H. Abdurahman A. Basalamah (19841994), II. M. Mokhtar Noer Jaya, SE, Msi (1994 -1998), Prof. Dr. H. Mansyur Ramly (1998-2003), Prof. Dr. H. M. Nasir I Iamsah (2003-2010). (Wanwancara oleh penulis tanggal 4 April 2009 cengan Mustari Beddu, Kepala Biro Admitrasi Akademik dan Kcmasiswaan)

Visi LMI Menjadikan universitas sebagai lembaga pendidikan dan dakwah yang terkemuka, melahirkan manusia berilmu amaliah, beramal ilmiah. dan berakhlaqui karmah, rerutama yang terkait dengan pengembangan ilmu pengetahuan, teknologi, kescnian dan budaya calam rangka syiar Islam serta memperjuangkan kepentingan umat secara global sebagai wujud pengabcian kepada Allah swt.

Misi UMI, Membentuk manusia yang berilmu amaliah, beramal ilmiah dan bcraktlaqul karimah yang adaptif, transformatif dan inovarif. Mengembangkan Ilmu Pengetahuan, Tekrologi, Kesenian dan Budaya dalam rangka pembuktian dan pengejawantahan kebenaran Allah swt., dan pengembangan Syariat Islam.

Tujuan/Sasaran UMI, Untuk mewajudkan visi dar: misi UMI tersebut di atas, maka aktivitas pendidikan dakwah dalam lingkup UMI diarahkan untuk mcwujudkan sasaran scbagai berikut: a. Meningkatkan peranan UJMI dalam mengembangkan ilmu penge:ahuan, teknologi, dan seni; b. Membentuk mahasiswa UMI menjadi teraga yang ahli, terampil berbudi luhur, can hertakwa kepada Allah swt untuk mengabdi kepada agama, bangsa, dan negara; c.Mclahirkar luaran yang berwawasan keilmuan dan keimanan, beramal ilmiah, dan berilmu amaliah, serta memiliki budi pekerti luhur yang senantiasa memancarkan akhlak yang mulia dan semangat yang ikhlas; $d$. Menjadikan UMI sebagai perguruan tinggi terkemuka dan dapat menjadi panutan dalam penegakan cita-cita luhur syiar Islam; e. Berperan aktif dalam usaha perwujudan kesejahteraan dan Ukhuwah Islamiyah, khususnya di lingkup UMI.

Tugas UMI, Untuk merigaktualkan perwujudan tujuan atau sasaran UMI, maka tugas yang emban meliouti: a. Menyelenggarakan kegiatan pendidikan dan pengajaran gurra meruber tuk dar menghasilkan lulusan atau luaran yang sesuai dengan tujuan atau sasaran 
ljtihad, Jurnal Wacara Hukum Islam dan Kemanusiaan, Vol. 10, No. 2 Desember c010: 215-236

UNI. ๖. Menyelenggarakan kegiatan penelitian untuk mengembangkan ilmu pengctahuan, teknologi, dan seni. c. Menyelenggatakan kegiatan pergabdian kepada masyarakat sebagai wahana untuk menerapkan dan mengamalkan ilmu pengetahuan serta menyemarakkan syiar Islam.

Kontribusi Terhadap Kesejahteraan Umat. Berdasarkan studi empiris penulis pada Yayasar Wakaf UMI, terungkap bahwa sejak tahun 1994 Yayasan Wakaf UMI cenderıng mengalami peningkatan yang cukup signifikan. Dalam hidang pendidikan, UMI telah membuka jenjang studi strata dua (\$2), dan berlanjut sampai tahun 2008 telah dibuka lagi jenjang studi strata tiga (S3). Dalam bidang dakwah (1994) mulai dicanangkan "Cuti Daci” ke berbagai dacrah di Sulawcsi Sclatan bagi dosen dan karyawan scrta para mahasiswa semester akhir, dengan prioritas daerah asal masing masing. Hal itu dimaksudkan sebagai kontribusi pembumian syiar Islam dan pembinaan umat khususnya di daerah-daerah marginal. Berkenaan dengan itu, H. Abdurahman A. Basalamah selaku Rektor UMI menggagas perlunya pembinaan umat melahui Desa-Desa Binaan UMI di wilayah Sulawesi Selatan dan di kawasan Timur Indonesia, sehingga sampai dengan periode tahun 2009, Yayasar Waka UMI tclah melakukan kerjasama dengan Desa Binaan UMI sebanyak 29 Desa Binaan yang terscbar dalam 23 Kabupaten di kawasan Timur Indoncsia (Mcdia Fitrah UMI, 1995: 1).

Berawal dari program Desa Biraan UMI, sejak tahun 1994 sampai sekarang, Yayasan Wakaf UMI telah membebaskan biaya pendidikan lebih dari 1.000 orang mahasiswa selama studi dalam berbagai fakultas. Kemudian mahasiswa binaan yang telah selesai sarjana di pulangkan ke daerah masing-masing untuk direkomendasi sebagai Sarjana Pengabdi Desa (SPD), kepada mereka diberikan insentif tiap bulan Rp 200.000 , sementara dalam kurun waktu 5 tahun terakhir, jumlah SPD akrif 100 orang. Apabila ada SPD yang yang terangkat PNS atau pekerjaan swasta, maka kekosongan itu diisi oleh alumni binaan yang baru, demikian itu seterusnya Wawancara penulis dengan Abd. Rauf Assagaf, Kapus LPMD UMI, tanggal 21 Marct 2009 di Makassar).

Selanjutnya program pencanangan unit unit usaha, setting unit-unit usaha tersebut diharapkan dapat membantu Yayasan dalam pembiayaan di bidang pendidikan, penelitian, pengabdian pada masyarakat dar pembinaan umat.

Unit-unit Usaha Yayasan Wakaf UMI. Terdiri dari pertama, Bayt al-Mäl wa al-Tamnìl 
Ukhuwah", setting lembaga keuanyan ini schagai sarana yarg nemfasilitasi pengelolatr: keuangan YW-UMI, thek anisme nembayaran mahasiswa cukup melalui BYTU. Di samping itu, BVTU mezupakan service sirspan pinjam khususnya bagi dossen dan karyawan UMII dengan menganut prinsip dan sistem bagi hasi, dalam kategorl pinjaman tanpa agunan. Kedua, PT. Ukkuwah UNI Tekrik yang hergerak di biàang real estate dan kontraktor. YWUML sedikiniva telah mengelok empat lokasi real ustate bidang perumahan, baik perumahan untuk dosen dan karyawan, maupun pcrumahan umum di mana manajemen pekerjaanya dilakukan sendiri oleh PT Ukhuwah UMI Teknik sebagai kontraktor, demikjan juga pada setiap pembangun dalam internal kampus UMI dan tawaran pekerjaan dari ekternal YWWUMI. Ketiga, PT. Ukhuwah UMI Bisnis, yang bergerak di bidang perdagangan umum. Melahui unit usaha ini telah cilakukan kerjasama perdagangan dengan beberapa mitra Lsaha, baik dalam negeri maupun luar negeri. Keempat, PT. Ukhuwah UMI Inciustri, bergerak ii hidang air minum kemasar gelas הengan merck "Wkhuwah", telah terdistribusi di scluruh wilayah Sulawesi Selatan, dan berdasarkan uji sterilitas dapat bersaing dengan air mirum merek "Aqua". Kelima, PT. Umihtōha Ukhuwah Grafika, bergerak di bidang percetakan dan penerbitan. Melalui unil usaha ini, sudah lianyak luku-buku yang diterbitkan, dan semua kepentingan disain cetak mencctak dapat tclah dapat dilayani ter.tama untuk kepentingan interen UMI.

Kesehatan dan Dakwah. Yayasan Wakaf UMI ticak hanya bergerak di bidang pendidikan can dakwah serta usaha dan dakwah, tetapi juga keschatan dan dakwah, dengan beropcrasinya Rumah Sakit "Ibnu Sina" yang sebelumnya bernama Rumah Salkit "15". Peralihan rumain sakit ini dilakukan pada tanggal 16 Juni 2003, dan peresmian penggunaannya pada tanggal 17 Mei 2004 (wawancara penulis dengan H. Muchtar Noex Jaya Ketua Pengurus Yayasan Wakaf LMI tanggal 25 Maret 2009 di Makassar).

Rumah Sakit "Ibnu Sina" YW-UMI mempunyai fasilitas dan kemampuan menyelenggarakan berbagai jenis pelayanan, di samping sel agai pelayanan medis, juga berfungsi sebagai

rumah sakit pendidikan bagi profesional kesehatan dari berbagai jenjang pendidikan bidang kesehatan.

Dalan mengelola yayasan in pra penetima amanah menerapkan manajemen Islam, sehingga semuc jabatan yang ada dalam lingkup organisasi yayasan (lembaga pendidikan, 
ljtihad, Jurnal Wacana Hukum Islam dan Kemanusiaan, Vol. 10, No. 2 Desember 2010: 215-236

unit usaha dan rumah sakit), didefinisikan sebagai amanah. Sebagai amanah, maka apapun nama dan level dari jabatan yang dipercayakan, harus dipandang dan diterima sebagai pekerjaan mulia yang harus dipertanggungjawabkan kepada atasan, dan di hadapan Allah swt.

Yayasan Wakaf UMI sebagai pelayanan amanah berdasarkan Anggatan Dasar dan Anggran Rumah Tangga lebih berkonsentrasi pada pendidikan dan Dakwah. Oleh karena itu kata "dakwah" dan kata "Ukhuwah" merupakan jargon dan simbol sebagai ciri khas YW-UMI. Misalnya LPPM menjadi LPPMD atau Lembaga Penelitian Pengabdian Masyarakat dan Dakwah. Demikian pula dengan kata "amanah", dan "ukhuwah" pada uraian yang terdahulu dijelaskan, bahwa YW-UMI sebagai lembaga yang mengemban amanah suci harus dikelola dengan prinsip amanah dan ukhuwah serta dipertanggungjawabkan dunia akhirat.

Berdasarkan validitas data yang dilakukan Direktorat Pemberdayaan Wakaf tahun 2007, bahwa dari kuantitas lokasi tanah wakaf di Indonesia tahun 2006 sebesar 403.845 lokasi, turun menjadi 366.595 lokasi, berarti penurunannya 37.250 lokasi (9,22\%). Tetapi dari aspek luasnya mengalami kemajuan yang sangat pesat, yakni dari luas tanah $1.566 .672 .406 \mathrm{~m}^{2}$ menjadi seluas $2.686 .536 .656,68 \mathrm{~m}^{2}$ atau naik $1.119 .864 .250,68 \mathrm{~m}^{2}(71.48 \%)$, atau 2.686 , $536 \mathrm{~km}^{2}$ dan atau 268.653, $66 \mathrm{Ha}$ (Harahap, 2008: 4).

Data luas tanah wakaf di Indonesia tersebut, apabila diasumsikan dengan luas wilayah DKI Jakarta $=656 \mathrm{~km}^{2}$, maka luas tanah wakaf Indonesia $=+4$ kali luas wilayah DKI Jakarta, atau mendekati 5 kali luas negara Singapura $=633 \mathrm{~km}^{2}$. Berdasarkan uraian kuantitatif tersebut dan dengan mengidentifikasi pengelolaan tanah wakaf secara empiris di lapangan, maka suatu kenyataan yang tidak bisa dibantah, bahwa wakaf yang ada di Indonesia pada umumnya berupa masjid, mushollah, madrasah, sekolahan, pekuburan, tumah yatim piatu dan Iain-lain. Dilihat dari segi sosial dan ekonomi, wakaf yang ada ternyata belum dapat berperan dalam menanggulangi problem sosial ekonomi umat. Hal ini dapat dimaklumi karena kebanyakan wakaf yang ada kurang maksimal dalam pengelolaannya. Dengan demikian jika wakaf dikelola secara produktif tentu akan berkontribusi terhadap pembangunan secara signifikan, baik di bidang ekonomi, agama, sosial budaya, politik, maupun pertahanan dan keamanan. 
Optimalisasi sistem pemberdayaan wakat produklif...(Muh. Shaleh Suratmin)

Menurut Rachmat Djatrika, dalam bidang ckonomi, wakaf memegang peranan semacam pershockbrcaker dalam keseimbangan kchidupan masyarakat karena dapat menutupi kebutuhan masyarakat yang vital (Djatnika, t.th.: 78).

Menurut hemat penulis, setidaknya ada tiga konsep dasar dalam mengelola wakaf secara produktif di Indonesia agar dapat berkembang signifikan. Pertama, perlunya optimalisasi penerapan sistem perwakafan, dengan mengoptimalkan pengelolaan tanah wakaf dan atau wakaf benda tidak bergerak secara produktif. Kedua, memberdayakan wakaf benda bergerak dan wakaf tunai, sebagai langkah antisipasi kurangnya minat masyarakat untuk berwakaf tanah, dengan dalih harga tanah semakin tinggi. Ketiga, menganut struktur lembaga Departemen dan Kementrian Perwakafan yang bertanggung jawab secara independen.

Apabila ketiga konsep tersebut dapat diimplementasikan secara signifikan, maka emisivitas atau daya pancar wakaf produktif sangat dimungkinkan menjadi alternatif sumber ekonomi yang dahsyat di Indonesia. Contoh dengan asumsi sederhana, kalau semua lokasi pekuburan yang umumnya menempati tanah betstatus wakaf, kemudian setiap lokasi pekuburan dapat dikelola secara produktif, maka hal itu dapat dibuktikan secara empiris bahwa para penjaga/ pengelola pekuburan pun akan dapat hidup sejahtera/layak. Sistem ekonomi umat melalui pengelolaan wakaf benda bergerak dan wakaf tunai yang diatur oleh Departemen dan Kementrian Wakaf yang bertanggung jawab secara independen, maka dapat dipastikan akan berimplikasi positif pada perubahan kondisi perwakafan yang signifikan.

Deskripsi empiris sebagaimana telah diuraikan terdahulu, seyogyanya dapat menjadi acuan pengelolaan wakaf secara produktif di Indonesia, mengingat potensi tanah wakaf di Indonesia sangat besar, juga merupakan negara yang berpenduduk muslim terbesar di dunia. Oleh karena itu pemberdayaan wakaf produktif seharusnya menjadi perhatian prioritas pemerintah Indonesia dalam hal ini Departemen Agama, mengingat sebagian besar kehidupan masyarakat Indonesia masih dalam garis dhuafa. Pendekatan yang harus digulirkan dewasa ini adalah penerapan sistem perwakafan dengan menganut struktur lembaga Departemen dan Kementrian Perwakafan yang bertanggung jawab secara independen.

Elaborasi terhadap deskripsi di atas, maka penulis mengidentifikasi, bahwa keberhasilan wakaf di beberapa negata khususnya di kawasan Timur Tengah, lebih disebabkan karena wakaf telah dikelola secara profesional dan karena besarnya perhatian pemerintah terhadap 
perwakafan, dan dilegitimasi dengan regulasi perundang undangan perwakafan yang signifikan. Hal itu dibuktikan dengan adanya pengelolaan wakaf yang secara khusus harus dipertanggungjawabkan oleh seorang menteri perwakafan. Dengan demikian pengelolaan wakaf dilakukan secara holistik dan komprehensip berdasarkan ketentuan perundangundangan yang berlaku, dan sepenuhnya menjadi tanggungjawab menteri perwakafan.

Berbeda dengan di Indonesia, perwakafan belum mendapat perhatian serius oleh pemerintah, dalam hal ini Departemen Agama yang secara yuridis mengemban amanah dan tanggungjawab terhadap pengelolaan wakaf di Indonesia, namun kenyataannya perhatian terhadap wakaf masih termarginal, dibandingkan dengan perhatian terhadap zakat, infaq dan șadaqah. Hal itu terbukti adanya pemberlakuan Perda Zakat di beberapa daerah di Indonesia, dan penggunaan tema-tema dakwah yang sering bersentuhan dengan zakat, infaq dan șadaqah karena dipandang dapat memberi kontribusi untuk kesejahteraan, sementara wakaf sangat kurang tersentuh dalam fenomena dakwah Islam. Hal itu menggambarkan bahwa menteri agama di Indonesia mempunyai tugas dan tanggungjawab yang sifatnya komptehensip dan integral dalam dimensi keagamaan yang diakui oleh negara, dengan demikian tidak mungkin dapat fokus terhadap perwakafan.

Di samping itu, dalam sistem perwakafan terdapat peluang ekonomi produktif yang sangat dahsyat untuk kesejahteraan umat. Syarat fundamental untuk mengelola wakaf secara produktif dari seluruh lini, harus profesional dan amanah, menerapkan sistem "otonomi berkehormatan dan berkebajikan” agar terhindar dari korupsi, kolusi dan nepotisme.

Telaah penulis tentang fektifitas penerapan Undang-undang Republik Indonesia Nomor 41 Tahun 2004 tentang Wakaf yang ditindaklanjuti dengan Peraturan Pemerintah Nomor 42 Tahun 2006, dapat dikategorikan belum efektif. Berdasarkan hasil penelitian terungkap, bahwa selama berlakunya Undang-undang Perwakafan dalam kurun waktu 5 tahun terakhir, menunjukkan belum juga berpengaruh secara signifikan. Hal itu teridentifikasi pada kondisi empiris perwakafan pra dan pasca berlakunya Undang-undang Perwakafan, secara umum belum ada perbedaan yang signifikan dan menggambarkan adanya resistensi (ketidaksesuaian) antara das sein dan das sollen. Faktor yang paling dominan menjadi penyebab tidak efektifnya Undang-undang Perwakafan tersebut adalah karena sangat kurangnya sosialisasi. Hal itu mendeskripsikan sangat kurangnya perhatian pemerintah dan atau aparat terkait, serta tidak 
berfungsinya peran Badan Wakaf Indonesia.

Konsep dasar optimalisasi penerapan sistem perwakafan di wilayah hukum Indonesia melalui setting revitalisasi Pola Pembinaan Wakaf Produktif, meliputi: pertama, pembinaan internal pejabat teknis perwakafan. Setting ini dimaksudkan untuk menyamakan persepsi para tenaga teknis yang membidangi perwakafan terhadap pentingnya pengelolaan wakaf secara produktif menurut perundang-undangan yang ada. Kemudian pembinaan ekternal yang bersifat massif (masyarakat), dengan melibatkan lembaga-lembaga profesional dan seluruh masyarakat agar ikut berpatisipasi menggerakkan dan meningkatkan kesejahteraan umat melalui pengelolaan wakaf secara produktif. Kedua, pembinaan manajemen organisasi dan penunjukan nazirir. Setting ini dipandang perlu segera diimplementasikan mengingat organisasi kenaģiran yang ada saat ini pada umumnya masih mengaktualkan pola tradisional. Kemudian pembinaan pengelolaan dan profesionalitas manajemen. Setting peningkatan profesionalitas manajemen kenazịan mutlak diperlukan, untuk menstresing wakaf agar berkontribusi dalam peningkatan kesejahteraan umat. Ketiga, pembinaan administrasi dan sanksi hukum. Setting ini penting mengingat administrasi perwakafan di Indonesia umumnya masih rancu, bahkan tertib administrasi di lingkup pejabat teknis (Departemen Agama) tergolong belum signifikan, jauh dari yang seharusnya, terkesan berjalan apa adanya disebabkan minimnya dukungan terhadap peraturan dan kurangnya potensi menjabarkan peraturan perundang-undangan yang ada. Konteks pembinaan sanksi hukum dipandang sangat penting sebagai upaya pengamanan harta wakaf dari perbuatan melawan hukum.

Selanjutnya optimalisasi sistem pemberdayaan wakaf produktif dapat dilakukan dengan cara, sebagai berikut: pertama, rekonstruksi wakaf yang dipandang potensial (strategis) untuk diproduktifkan, misalnya membuat kios, mini market, rumah sewa atau wisma penginapan, perbengkelan otomotif, penerbitan dan percetakan, dan sebagainya yang dapat menghasilkan nilai tambah secara ekonomis. Kedua, membuat rancangan tatakelola pendistribusian, hasilnya dengan tataran peningkatan kescjahtraan umat, meminimalisir kemiskinan dengan pola dana bergulir melalui Bayt al-Măl wa al-Tamwil (BM'), koperasi atau mekanisme perbankan syariah. Ketiga, mencanangkan program sosialisasi wakaf tunai dan atau wakaf uang secara intens selama kurun waktu 5-10 tahun ke depan melalui pola kemitraan dengan bank-bank syariah. 
ljtihad, Jurnal Wacana Hukum Islam dan Kemanusiaan, Vol. 10, No. 2 Desember 2010: 215-236

\section{Penutup}

Berdasarkan telaah strategis melalui pendekatan kualitatif dengan analisis deskriptif, maka optimalisasi sistem pemberdayaan wakaf produktif sebagai alternatif sumber ekonomi umat di Indonesia disimpulkan sebagai berikut, bahwa dalam upaya optimalisasi sistem pemberdayaan wakaf produktif di Indonesia perlu mengacu pada sistem pengelolaan wakaf produktif dan atau wakaf tunai di Mesir, Saudi Arabia dan Yordania yang secara empiris telah berkontribusi yang sangat besar terhadap kesejahteraan umat melalui manajemen sistem kementrian wakaf. Pengelolaan wakaf dengan sistem manajemen otonomi berkehormatan dan berkebajikan sangat berpeluang untuk diimplementasikan dalam upaya mengoptimalkan pengelolaan wakaf secara produktif di Indonesia.

Dalam wakaf terdapat peluang ekonomi produktif yang sangat besar untuk kesejahteraan umat, bangsa dan negara Republik Indonesia. Namun peluang besar itu baru dapat terwujud, apabila ada perubahan pemikiran dari internal umat Islam tentang wakaf dari konvensional menjadi madani (modern) dengan benar-benar memahami dan menghayati wakaf sesuai dengan konteks ekonomi Islam, sehingga pembangunan wakaf terpelihara dari praktek ekonomi sosialis dan kapitalis yang dapat merusak citra pembangunan wakaf itu sendiri.

Dalam upaya mewujudkan pembangunan wakaf yang betkontribusi kepada kesejahteraan umat, harus ada interes (kemauan) keras umat Islam untuk mengelola dan mengembangkan wakaf secara produktif. Di samping itu, untuk mengclola wakaf dari seluruh lini harus profesional dan amanah serta terhindar dari KKN.

\section{Daftar pustaka}

Al-Khatib, Muhammad. al-Iqñás. Bairut: Dār al-Ma'rifah, t.th.

Al-Zuhayli, Wahbah. Al-Wasit fi Ușul al-Figh. Damaskus: Maktabah al-'Ilmiyyah, 1969.

Al-Zuhailiy, Wahbah, Al-Fiqh al-Istami wa Adillatubs. Kairo: Dār al-Fikri, t.th.

al-Kubaisy, Muhammad 'Ubaid. Abkēam al-Waqf Sbari'at al-Islamiyab. Baghdad: Matba'ah al-Irsyad, 1977.

Al-Shan'any, Muhammad ibn Isma'il. Subul al-Salam. Mesir: Muhammad Ali Sabih, t.t.

Buku Panduan UMI Makassar tahun 2008/2009.

Departemen Agama RI. Model Pengembangan Wakaf Produkiff. Jakarta: Direktorat Jenderal Ditjen Bimas Islam Direktorat Pemberdayaan Wakaf, 2007. 
Departemen Agama RI. Al-Qw'an dan Terjemabnya. Semarang: Karya Toha Putra, 2002.

—, Departemen Agama RI.Undang-Uindang Republik Indonesia Nomar 41 Tabun 2004 Tentang Wakaf, dan Peraturan Pemerintab Nomor 42 Tabun 2006 Tentang Pelaksanatannya. Jakarta: Ditjen Bimas Islam, 2007.

Departemen Agama RI. Strategi Pengamanan Tanah Wakaf. Jakarta: Ditjen Bimas Islam dan Penyelenggara Haji, 2004.

Djatnika, Rachmat. Wakaf Tanah. Surabaya: Al-Ikhlas, t.th.

Djunaidi, Achmad dan Thobieb Al-Asyhar. Menuju Era Wakaf Produktif Sebuab Usaba Progresif untuk Kesejabteraan Umat. Cet. ke-2; Jakarta: Mitra Abadi Press, 2005.

Echols, John M. dan Hassan Sadily. Kamus Inggris-Indonesia Cornell University Press, Ithaca and London Jakarta: Pen. Gramedia Pustaka Utama.1996.

Hafidhuddin, Didin. "Wakaf Uang dalam Pandangan Syariat Islam" dalam Imam Abu Husein Muslim bin Hajaj Șạih Muslim. Juz III. Diterjemahkan oleh Adib Bisri Mușțafa dkk dengan judul Terjemahan Sabib Muslim, Cet. ke-1. Semarang: Asy-Syifa', 1993.

Harahap, Sumuran. "Kebijakan Pemerintah dalam Pengelolaan Wakaf". Makalah disampaikan pada Acara Kagiatan Temu Konsultasi Pejabat Teknis Perwakafan dengan Lembaga Keuangan Syari'ah di Hotel Alia Cikini, Jakarta: pada tanggal 27 Agustus 2008.

Hasanah, Uswatun. "Manajemen Kelembagaan Wakaf", Makalah Workshop Internasional, Pemberdayaan Ekonomi Umat Melalui Pengelolaan Wakaf Produktif, Batam: Departemen Agama RI. Jakarta: Ditjen Bimas Islam dan Penyelenggara Haji Direktorat Pengembangan Zakat dan Wakaf, Januari, 2004.

Khallaf, Abdul Wahhab. Aḅkäm al Waqf. Kairo: Mațba'ah al- Mișr, 1951.

Mannan, Mohammad Abdul. Cash Wagf Certificate, An Innovation in Islamic Finansial Instrwment. (Sertifikat Wakaf Tunai, Scbuah Inovasi Instrumen Keuangan Islam), Alih bahasa Tjasmijanto Rozidyanti (ed.) Mustafa E. Nasution Sunarsip, Pen. CIBER/PKTTI-UI, Depok: 2001.

Mannan, Muhammad Abdul. Teori dan Praktik Ekanomi Islam. diterjemahkan oleh M. Nastangin, Yogyakarta: Dana Bhakti Wakaf, 1993.

Media Fitrah UMI, edisi Juli 1995.

Qardawi, Yusuf. Problema Kemiskinan, Apa Konsep Istam. Tcrjemahan Umar Fanani, Surabaya: Bina Ilmu, 1982.

Sabiq, Sayyid. Figh as-Sunnab. Jilid III, Beirut: Dār al-Fikri, 1983.

Saefuddin, M. Ahmad. Ekonomi dan Masyarakat Dalam Perspektif Islam. Jakarta: Rajawali Press, 1987. 
ljtihad, Jurnal Wacana Hukum Islam dan Kemanusiaan, Vol. 10, No. 2 Desember 2010: 215-236

Siddiqi, Muhammad Nejatullah. Mushm Economic Tbinking. Terjemahan A. M. Saefuddin, Jakar-ta: LIPPM, 1986.

Suratmin, Muh. Shaleh "Optimalisasi Pencrapan Sistem Perwakafan dalam Meningkatkan Kescjahteraan Umat” (Studi tentang Pengelolaan Wakaf di Kota Palopo Sulsel), Discrtasi Program Pasacasarjana UIN Alauddin Makassar 2009.

Syalabi, Muhammad Mustafa. Muhādarat al-Waqf wa al-Wastyat. Iskandariyah: Dār al-Ta'lif, 1957.

Wojowasito, S. Kamus Umum Belanda Indonesia. Jakarta: Ichtiar Baru Van Hoeve, 1981.

Zahrah, Muhammad Abu. Muhädarat fi al-Waqf. Kairo: Där al-Fikri al-Araby, 1971.

Zein, Satria Effendi M. "Analisis Yurisprudensi tentang Perwakafan", Mimbar Hukum, Nomor 4 Tahun ke-2; 1991. 